\title{
Married Life on the Brink: American Domesticity in Richard Yates' Revolutionary Road (1961)
}

\author{
Heba Waddah El-Sayed Ali \\ $\mathrm{PhD}$ researcher - Dept. of English Language \& Literature \\ Faculty of Women- Ain Shams University \\ hebawaddah82@gmail.com \\ Prof. Magda Hasabelnaby \\ Faculty of Women \\ Ain Shams University \\ Assoc. Prof. Rania Reda \\ Faculty of Women \\ Ain Shams University
}

\begin{abstract}
American domesticity in the second half of the twentieth century witnessed many changes. This is reflected in the family fiction of Richard Yates (1926 - 1992). This paper attempts to answer some questions regarding domesticity in Yates' first novel Revolutionary Road (1961). First, this novel documents social, economic, and cultural conditions especially in post-WWII America. Second, the author's autobiographical details add credibility to the novel. Although Yates has not written a separate autobiography, he depends heavily on true events and characters in writing this novel. Third, Yates tackles feminist domestic issues like women's work, marriage, and abortion. The novel depicts the heated conflict of the age, namely the pro-family VS the pro-feminist. Through the portrayal of three families living in the American suburbs at that age, Yates manages to show readers how married life can sometimes reach a dead end and, in turn, the whole society crumbles.
\end{abstract}

Keywords: American literature, domesticity, Yates, Revolutionary Road

According to Merriam Webster Dictionary, domesticity can be defined as "life inside a home: the activities of a family or of the people who share a home." While domesticity is an umbrella term for all themes related to life inside a home, family fiction is a sub-genre of fiction that tackles these domestic themes, e.g. marriage, singlehood, or the generational gap. A family is just a microcosm of the whole society. It reflects political, cultural, social, and 
economic conditions. Thus, to analyze a certain community, one should examine some family case studies. This can be done through sociology, especially family sociology which is "the oldest organized intellectual discipline" (Zimmerman 87).

Fiction is loaded with examples of families that represent their society. Writing family fiction is considered one of the best methods for social documentation. In this type of novels, authors attempt to depict people within their families "continuously adjusting to a physical and social environment" (Groves 285). Family values and predicaments are represented in a way that changed along with the shifts that occur in society.

During the nineteenth century, Americans were equally concerned about broad national causes as well as private issues. According to Amy Kaplan, domesticity is defined as "both familial and national" (602). On the other hand, late-twentieth-century America was "shaped by political retreat, a turn to personal preoccupations, and narcissistic self-indulgence" (Zaretsky 187). Throughout the twentieth century, in the aftermath of the two world wars, American families were concerned about their own domestic predicaments rather than national ones.

The traditional division of labour within the American family was altered gradually. American women are no longer restricted to the private sphere of their homes while men enjoy the public realm of work outdoors. The title of Glenna Matthews' book "Just a Housewife" suggests American women's revolt against being restricted to mere domestic chores. In mid-twentieth century, Matthews clarifies, "the suburban, middle-class housewife was doubly isolated: physically, by the nature of housing patterns, and spiritually, because she had become merely the general factotum for her family" (xiii).

On the other hand, according to Elaine Tyler May, "the potential for a new model family, with two equal partners who shared breadwinning and homemaking tasks, never gained widespread support" (87). A pro-family vs. a pro-feminist conflict took place all over the States. The pro-family supporters started to defend the conventional family pattern and accused feminists of the breakdown of the American family through "divorce, abortion, and women working outside the home" (Conover 177). The pro-feminist advocates stressed women's rights including divorce, abortion, and work. Throughout several years, the American society has gradually been shaped and reshaped until it has reached the dual-earner family pattern of today. 
The constantly changing American macrocosm is reflected in the literary microcosm of family fiction. One of the American novelists who were dedicated to writing family fiction is Richard Yates. Although the domestic novels by Yates tackle issues closely related to his personal life, they prove to have a timeless universal significance. They deal with the American domestic life during the second half of the twentieth century showing that history repeats itself all over the world regarding family issues like breadwinning and homemaking.

This paper tackles American domesticity as exemplified in Richard Yates's Revolutionary Road ${ }^{1}$ (1961). The focus is on marriage as the main domestic relationship. The novel discusses post-WWII America as a macrocosm. It investigates how far the social, economic, and cultural conditions of America affected the author as an American married citizen, whose life represents the life of the majority of married couples at that time.

In an attempt to sublimate a tough childhood and later two failed marriages, Yates wrote family fiction that attempts to represent American domesticity based on his own experience as a husband and a father of three daughters. Jonathan Penner sums up the complexity of Yates's domestic experience as follows:

Like a great jigsaw puzzle, the territory of Yates's work knits together as it expands. Certain experiences have emerged as central to his fiction World War II and its scars; growing up with a bohemian mother divorced from a plodding father; prep school education; a stifling job in public relations or advertising or sales; physical and mental illness. (43)

For instance, his first novel $R R$ delineates the hard married life of an American couple in the 1950s. The male protagonist Frank Wheeler resembles Yates himself.

Charles Baker claims that Yates's novels hold the mirror up to the grim reality of mid-twentieth-century America. Baker relates the details of this modern American novelist to the incidents of his (Yates's) debut novel $R R$ :

\footnotetext{
${ }^{1}$ The title will be abbreviated as $R R$ throughout the body of the paper.
} 
We are drawn to Yates's work the same way we are drawn to take a quick glimpse of ourselves in the glass of a shop window while walking down a sidewalk. We may not like everything we see, but we cannot deny the honesty of the reflection.

Tony Hilfer, on the other hand, argues that Yates's $R R$ is "the classic family horror novel" (187). It portrays a female protagonist named April married to middle-aged Frank Wheeler, parenting a boy and a girl, and living in Revolutionary Road at the suburbs of Connecticut. Although it may sound like a perfect family, the Wheelers have a married life on the brink. The names of the main characters do not refer to their real traits; and this choice adds to the satirical tone of the novelist: April is straightforward and she cannot be related by any means to the tricks played on April Fool's Day. By contrast, Frank keeps on acting and hiding real intentions, thoughts, and feelings till the very end.

In an attempt to escape her boring daily domestic routine, April joins a group of amateurs in acting a play that was their first and last production, namely The Petrified Forest (1935) by Robert Sherwood. Playing the role of Gabrielle on stage foreshadows April's aborted future as an actress. Yates uses the technique of the play within the novel to introduce readers with an American dream that never comes true: "The play - in the novel - serves as a metaphor for the Wheelers' marriage ... Their realization, as the months pass, of the widening gap between their idea of themselves as special people and the reality of being like everyone else makes them take drastic steps with tragic results" (O'Nan).

April, who proves to be a bad actress on stage, struggles to act in real life. She complies with the rules of society, and tries to please people around. Her grim reality forces her to search for happy moments in her past life with Frank and replay them in dreamlike flashbacks. One example is when she recalls the first day she sees her new house on Revolutionary Road as she moved from the city to live in the suburbs: "[t]his was the way they had first come, two years ago, as cordially nodding passengers in the station wagon of Mrs. Helen Givings, the real-estate broker" ( $R R$ 38).

Several critics, including Baker and Hilfer, conceive Yates as a realist. For instance, Adelle Waldman demonstrates how Yates mingles "the psychological sophistication of realism and the mercilessness of satire." Eric 
Ormsby observes that "the pathos in his fiction always emerges from exact depiction." Further, John Sutherland writes that Yates was "born into an impoverished and dysfunctional family whose dysfunctions and monetary crises he reproduced with Xerox fidelity." In addition, critics document the postWWII changes in his novels: "moral let-down, loss of morale, a sense of futility and disillusionment, and most especially discontent and restlessness" were all evident in the overall atmosphere of Yates's Revolutionary Road (Groves 295). Moreover, Crista DeLuzio states:

Geographic mobility, absent fathers, and working mothers, as well as the high rates of neuropsychiatric disorders diagnosed among America's soldiers, concomitantly initiated widespread cultural anxieties about the state of the family and hastened the rapid growth of psychoanalytic psychiatry as the postwar period began. (125)

By the time Yates wrote $R R$, "he graduated from the Avon School in 1944, served in the last years of World War II, and until 1952 worked at a variety of jobs" (Henry, et al. 65). The repercussions of WWII are concisely represented in the significant talk between the Wheelers and John, the mentally unstable son of the real-estate agent Mrs. Givings. In just two words, Frank summarizes all the stifling reasons behind his decision to travel to Paris for good, namely "the hopeless emptiness" ( $R R$ 258). April, who had that wishfulthinking plan, adds in a private chat with Frank, "He's the first person who's really seemed to know what we're talking about." Then Frank confirms, "That's true... I guess that means we're as crazy as he is". ( $R R$ 263)

This conversation was the last one in which Frank and April showed they were on good terms. Although they talk a lot, they always lose control over their temper, get into frequent fits of anger, and sometimes fail to communicate any meaning.

In his novel, Yates sticks to several autobiographical details which reflected his own, and his family's lives. First, Frank is the same age as Yates himself when writing the novel. Both are thirty years old. Second, April is closely modeled on Yates's first wife:

Sheila was not keen on the idea of having children and was desperate to get a job and do something challenging with her life. Both before and after the birth of their two daughters, this was a source of tension between 
them, and when they finally divorced in 1959 , Sheila began training as a teacher. (Charlton-Jones, et al. 165)

Third, like the author, the protagonist (Frank) is only left with hatred and bitterness from his parents. Long after their death, Frank recalls back the feeling of being rejected that he used to have when his parents were still alive. Talking to his new boss about his father who worked at the same company but died without a trace, Frank wishes to forget his painful past: "He already had two full-grown kids by the time I was born, you see - I was the accident, you see; I was the one they didn't want" ( $R R$ 273). Likewise, April's parents did not care about her since she was born; she inherited sad memories and a depressive character. In brief, April's family proves to be typically dysfunctional: she is an only child whose parents were divorced within a year of her birth; she was raised up by several aunts; her father shot himself and her mother died after many years wasted in an alcoholic retreat.

Moving from the city to the suburbs, the Wheelers have to lead a life of cooperation and conformity. In her book The American Family System, Sister Frances Jerome Woods notes that suburbs are called the "second great melting pot" (172). The Wheelers have to wear masks, offer help and justify their decisions to their suburban community, namely the Givings and the Campbells. "Although each home may be a unit looking inwards to itself", wrote Peter Bromhead, "it is also a unit which is much involved with the activities of the homes round about it" (199). The Wheelers are committed to a series of Sunday visits by the Givings as well as a bunch of mutual visits and outings with the Campbells.

The Campbells have been the closest friends and neighbours. Still, they look up to the Wheelers and find their plan to leave for Paris unrealistic. Shep and Milly have four sons. Milly is a typical housewife who takes care of her children and sometimes the Wheelers' kids too, whereas Shep hates even the sight of his own sons:

He almost tripped over them. They were lying on their bellies in a row, their eight-, seven-, five-, and four-year-old bodies identically dressed in blue knit pajamas... "Hi, gang," he said, but none of them looked up. He walked carefully around them and out to the kitchen, frowning. Did other men ever feel distaste at the sight of their own children? (RR 199) 
Shep does not reveal his love for April except near the end, when she is pregnant and unable to have her dream come true. With a wide gap between the Wheelers, both April and Frank have their extramarital affairs. They reach a point of neither return nor divorce.

Regarding the Givings, they have been living in the suburbs for more than a decade. Every couple of years, Mrs Helen Givings, a real-estate broker changes the house she lives in with her husband while their son John is kept at a psychiatric asylum. In front of others, she tries to be sociable and friendly; however, the stigma of her son's mental illness keeps her weeping all alone and wondering about an outlet:

Wouldn't it do John a world of good to recuperate among a few sensitive, congenial people of his own age? And there need be no question of altruism on the Wheelers' part: hadn't they all but told her, time and again, how starved they were for friends of their own kind? (RR 218)

The Wheelers' decision to leave for Paris comes as a shock for the Campbells and the Givings. The Wheelers, in turn, justify their decision and explain the reasons behind their revolutionary plan. Only the Wheelers, especially April, cannot bear "the hopeless emptiness" ( $R R$ 258) of the American suburbia. Cicely Palser Havely asserts that "the original American Revolution (against British rule) was fought for the citizens' right to live as an independent community." It was the famous American dream that turned into a nightmare with most of Americans moving to the suburbs in the 1950s. Sharing the same suburban life, the Campbells always look up to the Wheelers believing - like the Givings - that they are special and perfect. Yates sums up the life of mid-twentieth-century Americans in a single line followed by a wise piece of advice addressed to the reader:

deadly dull jobs in the city and deadly dull homes in the suburbs. Economic circumstances might force you to live in this environment, but the important thing was to keep from being contaminated. The important thing, always, was to remember who you were. ( $R R 27)$ 
April, the spokesperson of the author, tries hard to convince her husband of her plan to escape that dull life. Whenever Frank, like the Campbells and the Givings, replies with a practical point of view, April insists on her dream:

that people have to resign from real life and 'settle down' when they have families. It's the great sentimental lie of the suburbs... and I guess this is what really brought it home to me - this picture of myself as the girl who could have been The Actress if she hadn't gotten married too young. And I mean you know perfectly well I was never any kind of an actress and never really wanted to be; you know I only went to the Academy to get away from home, and I know it too. ( $R R$ 153)

Having a turbulent domestic life since an early age, April always escapes commitment and revolts against the stereotypical American woman of that age.

When April discovers that she is pregnant, Frank takes a moral position and rejects her decision to have an abortion. Further, he sees April as a dreamy immature unbalanced woman who needs psychiatric help:

I mean things that have nothing to do with Europe... or with me. I mean things within yourself, things that have their origin in your own childhood - your own upbringing and so on. Emotional things... Wasn't it likely, after all, that a girl who'd known nothing but parental rejection from the time of her birth might develop an abiding reluctance to bear children? $(R R$ 307)

Frank uses a negative self-defense mechanism, namely projection. It is he who feels rejected since an early age; still, he judges and decides that it is April who needs to see a psychiatrist. To Frank, April's insistence on travelling to Paris is seen as an impulsive wish and an escape from her duties as a mother and a housewife. After she knows about her pregnancy, she should take a logical decision of staying at home and preparing for the arrival of a third child.

When the Wheelers see John Givings - the mentally disordered mathematician for the first time, they like his frankness. However, in their latest struggle to choose between duty and passion, they start to judge him differently:

"The man," he [Frank] said again, "is insane. Do you know what the definition of insanity is?" 
"No. Do you?"

"Yes. It's the inability to relate to another human being. It's the inability to love."

$\cdots$

"Oh," she [April] said... So now I'm crazy because I don't love you right? Is that the point?" (RR 396-97)

Only then, April loses patience with Frank. From the very beginning, April proves to be a good housewife who cleans, cooks, cares for the children and cooperates with neighbors. However, she is unable to wear the mask of obedience and satisfaction anymore. Leaving the breadwinner Frank indoors, she escapes to the woods around smoking heavily and trying hard to decide what to do next.

Through these autobiographical elements, Yates's novels are concerned with feminist issues such as abortion, women's freedom and the relationship between men and women, especially a man and his wife; "In his early work, including Revolutionary Road, Yates's depiction of the struggles men, and more particularly women, encounter within the home and outside it prefigure some of the concerns the second wave of feminism adopted" (Charlton-Jones, et al. 11). $R R$ includes the autobiography of Yates, his feminist concerns, and domestic affairs in general. As Julie Millhouse observes in her article, "homes of the Wheelers, Givings and Campbells, as well as Maureen Grube's singleton apartment, are dense with domestic props." The 1950s American suburbia is depicted with all minute details related to middle-class women and men including Yates himself. Though he did not write a separate autobiographical book, Yates leaves behind a fiction teeming with his life story as a talented author, a heavy smoker, an alcoholic, and a dreamer who was hospitalized more than once. Scanning his novels, especially $R R$, Michael Shinagel describes Yates as "the literary laureate of the loners and losers of middle-class America at mid-century and after" (50).

Published in 1961 and set in the 1950s, $R R$ tackles abortion as one of the catastrophic results of American feminism at that time. April hopes to get an abortion, escape the dull life of a homemaker in Connecticut and try the Parisian life as a breadwinner while Frank has time to find a suitable career as well. Kenneth Millard states: 
The success of the feminist movement enabled more women to pursue career paths and to postpone having children, women's conceptions of themselves were less likely to be determined by models of domesticity, and financial pressures have made large families less common as children are increasingly regarded in terms of economic commitment. (9)

While Frank supports the conventional family and decides to accept a promotion at Knox, pro-feminist April revolts against this old mold. As a couple, the Wheelers represent the "Pro-family vs. Pro-feminist" conflict widespread in the States at that age. Between the lines, Yates proves to be a profamily novelist; his novel states that "high divorce rates, high abortion rates, and women working outside the home all indicate the breakdown of the traditional American family" (Conover and Gray 175). While Frank aims at keeping his job for the sake of his wife and children, April is not ready to give up her dream of traveling to Paris and having a career.

Behind the doors of their house, the Wheelers are just like everyone else in the suburbs. Frank is the outsider who commutes daily to the city, works and gets money, and in turn power, whereas April is the one responsible for domestic chores like cleaning, cooking, washing dishes, and taking care not only of children but also of her neighboring community. Yates's female protagonist represents "women reporting that they spend at least three times as much time on these tasks as their husbands" (Coltrane and Adams 76).

The novel tackles all the conflicts between duty and love, breadwinning and vocation, reason and passion, responsibilities and whims, consumerism and minimalism. Frank represents the day-in-day-out priorities. He plays the role of the powerful breadwinner even if he hates his job. To Maureen Grube, a workmate with whom he had a love affair, Frank is "decent but disillusioned young family man, sadly and bravely at war with his environment" ( $R R 132)$. April, on the other hand, represents the passionate hunger for life outside the confines of home:

While American women were relegated to a separate domestic sphere in 1850, it was a sphere that was central to the culture. One hundred years later, most American women were still functioning as housewives in some fashion, but the home was no longer central, and this made the role of housewife much more problematic for those who filled it. In fact, by 
the mid-twentieth century many women had begun to think of themselves as "just a housewife." (Matthews xiii)

The twentieth-century version of domesticity is completely different. In Yates's $R R$, domestic life is hellish for all the female characters: Maureen Grube's short marriage is annulled; Mrs. Givings suffers all alone while her retired husband turns a deaf ear to her suffering; Mrs. Campbell has got four sons and wears a mask of a strong homemaker; the female protagonist April could not act on her "dreamy" plan.

With a baby on the way, Frank accepts the new job offer at Knox, while April is still wondering what to do with her dull domestic life at the suburbs. Her wishful thinking about life in Paris turns wistful with some flashbacks of herself as a little girl with no duties as a wife and a mother:

I still had this idea that there was a whole world of marvelous golden people somewhere... people who knew everything instinctively, who made their lives work out the way they wanted without even trying, who never had to make the best of a bad job because it never occurred to them to do anything less than perfectly the first time. Sort of heroic super-people, all of them beautiful and witty and calm and kind, and I always imagined that when I did find them I'd suddenly know that I belonged among them, that I was one of them. (RR 352-53)

The ending of $R R$ recalls to mind the suicide-or-accident endings of other realistic novels like Kate Chopin's The Awakening (1899) and Edith Wharton's The House of Mirth (1905). In an interview, Yates declares that his novel is "built on a series of abortions of all kinds - an aborted play, several aborted careers, any number of aborted ambitions and aborted plans and aborted dreams - all leading up to a real physical abortion, and a death at the end" (Henry, et al. 67). The ending of the novel leaves readers at a loss. Through the theme, the plot, the dialogue, the characterization, and narrative techniques such as the play-within-the-novel and flashbacks, Yates portrays a conflict that cannot be resolved easily. In Dismembering the American Dream, Kate Charlton-Jones observes that "Figures recur across his work, versions of himself acting out versions of his life... his fiction provides no happy endings" (8-9). This confirms what Jennifer Daly calls "the bleakness of [Yates's] vision" (40). 
On her final day before the fatal abortion, April proves to be a clever actress who plays the role of the submissive housewife. Frank wakes up finding his wife April in the kitchen preparing breakfast. He believes that she has finally surrendered and decided to reach a compromise. Ironically, however, April is unable to continue the habit of wearing masks to please others and decides to behave in accordance with her genuine self. It is only Frank who misses the fact that people do not change overnight. She blames herself for being married to him in the first place - "the only wrong and dishonest thing, was ever to have seen him as anything more than that. Oh, for a month or two, just for fun, it might be all right to play a game like that with a boy; but all these years!" (RR 416)

After April's death, Frank moved to New York where his married brother lives. The post-Wheelers life in Revolutionary Road does not change a lot. Milly Campbell told their story to new neighbours many times, whereas her husband Shep was really sad as he loved April. Mrs Givings is fascinated with the Braces - the new couple replacing the Wheelers; she declares, "I've loved that little house for years, and these are the first really suitable people I've ever found for it. Really nice, congenial people, I mean" ( $R R 461)$.

Mrs Givings will keep on judging houses and people. Julie Millhouse states: "Mrs Givings sells dreams of perfect domesticity to couples like the Wheelers, who are happy to step blithely into the world of material acquisition." She used to find the Wheelers special but now they are "neurotic"(RR 461). It is an endless struggle between conformity and revolt; and one wonders if the Braces will live happily ever after or they are just seemingly happy with life in the suburbs. Yates does not offer clear-cut answers.

Valid in the thirties as well as in the fifties, The Petrified Forest - the play that April had a leading role in - presents a story of frustration. Similarly, Yates's novel that was set in mid twentieth century proves to be applicable to the twentieth-first century with the successful 2008 movie. Receiving a Golden Globe for Best Actress, Kate Winslet thanked Yates for his novel that is timeless in its description of modern man's predicament. Lee Siegel, in his essay "The Second Coming of Richard Yates", justifies the 'culture of retrieval': "Weakly stimulated by the present, we compulsively return to the past." This explains why a twentieth-first movie based on a mid-twentieth-century American novel can be a hit even in a country other than America. 
As Kate Charlton-Jones observes, Yates "sought to avoid simplistic resolutions to the vast array of complex problems that accompany the human condition" (125). He is not concerned with just a single case study. Instead, he offers a snapshot of the whole American society and of modern man in general with the recurrent dilemma of choosing whether to compromise or give up on frustrated personal dreams: "the ending of Revolutionary Road leave[s] the reader considering issues that encompass loneliness, abortion, and suburbia" (Charlton-Jones, et al. 148).

$R R$ poses the question of whether the war on conformity will succeed or not - the answer seems to be on the negative side. The ending of the novel dramatizes the failure of the individual, especially the female in that respect. She is likely to suffer the moment she dares to think of swimming against the social tides of conformity. April's dreams that constantly pull her out of the socially prescribed framework as a wife and a mother are doomed to failure.

To sum up, Yates offers in his novel a brilliant documentation of the social, economic, and cultural conditions of the American domestic life during the fifties through his portrayal of the married life of Frank and April. The novel shows minute details of a two-year experience in the American suburbs at the fifties. Moreover, it clarifies the psychological impact of war on the American society. Americans lost morale and felt futile, dissatisfied, and restless. Both Frank and April had their extramarital affairs. April, just like many American women at that age, had a great passion for work outside home. She wished that she could be a breadwinner not just a housewife.

The pro-family vs. the pro-feminist conflict is represented by the characters of Frank and April respectively. While Frank supports the idea of having a third child and, therefore, he accepts a promotion at Knox, profeminist April wishes to escape the hellish conventional life at the suburbs. One of the catastrophic results of American feminism at that time was abortion. The physical abortion at the end of the novel signifies a mental abortion of traditional ideas. Yates is regarded as one of the pioneers in tackling American domestic issues in his novels. His $R R$ paves the way for feminists along with pro-family supporters to reach a compromise. To him, married life cannot last if the spouses are too stubborn to realize that it is not a matter of either-or. A successful marriage relies on mutual understanding and real consideration of needs. 


\section{References}

Baker, Charles R. "Richard Yates." American Writers: A Collection of Literary Biographies, Supplement 11. Ed. Jay Parini. New York: Charles Scribner's Sons, 2002. Literature Resource Center. Web. 4 May 2015. $<$ http://go.galegroup.com>.

Bromhead, Peter. Life in Modern America. London: Longman, 1970.

Charlton-Jones, Kate, et al. Dismembering the American Dream : The Life and Fiction of Richard Yates. Tuscaloosa: University Alabama Press, 2014.

Coltrane, Scott, and Michele Adams. "Men's Family Work." Working Families: the Transformation of the American Home. Edited by Rosanna Hertz and Nancy L. Marshall. Berkeley: California UP, 2001. 72-99.

Conover, Pamela Johnston, and Virginia Gray. Feminism and the New Right: Conflict over the American Family. New York: Praeger, 1983.

Daly, Jennifer. "Emily Grimes is me: Anxiety, Feminism, and the Masculinity Crisis in Richard Yates's The Easter Parade." IJAS. 2014: 40-47.

DeLuzio, Crista. "The Personal and Political Postwar American Family." American Studies. 54.4 (2016): 119-132.

"Domesticity." Merriam-Webster.com. Merriam-Webster, n.d.Web.13 June2015<http://www.merriamwebster.com/dictionary/domesticity>.

Groves, Ernest R., and Gladys Hoagland Groves. The Contemporary American Family. Chicago: J. B. Lippincott, 1947.

Havely, Cicely Palser. "Revolutionary Road by Richard Yates". The English Review 13.1 (2002): 14+. Literature Resource Center. Web. 4 May 2015. $<$ http://go.galegroup.com>.

Henry, DeWitt, et al. "From the Archive: An Interview with Richard Yates." Ploughshares 37.2/3 (2011): 65-78. 
Hilfer, Tony. American Fiction Since 1940._London: Longman, 1992.

Kaplan, Amy. "Manifest Domesticity." American Literature. 70-3. Sept. 1998:581-606.

Matthews, Glenna. Just a Housewife: The Rise and Fall of Domesticity in America. Cary, US: Oxford UP, 1989.

May, Elaine Tyler. Homeward Bound: American Families in the Cold War Era. New York: Basic Books, 2008.

Millard, Kenneth. Contemporary American Fiction . New York: Oxford UP, 2000 .

Millhouse, Julie. "Can't act, won't act: Julia Millhouse looks at the consequences of action, inaction and escapism in Richard Yates' Revolutionary Road." The English Review 21.1 (2010): 18+. Literature Resource Center. Web. 4 May 2015. <http://go.galegroup.com>.

O'Nan, Stewart. "The Lost World of Richard Yates: How the great writer of the Age of Anxiety disappeared from print" Boston Review. 1 Oct. 1999. 11 Feb. $2015<$ http://bostonreview.net/

BR24.5/onan.html>.

Ormsby, Eric. "The disaster parade." New Criterion 22.5 (2004): 69+. Literature Resource Center. Web. 4 May 2015. <http://go.galegroup.com>.

Penner, Jonathan. "The Novelists: Richard Yates". The New Republic. 4 Nov. 1978. pp. 42-45.

Shinagel, Michael. "Richard Yates: An Introduction." Harvard Review.25 (2003): 50-52.

Siegel, Lee. "The Second Coming of Richard Yates." Harper's Magazine 303.1814 (2001): 82. MasterFILE Premier. Web. 4 May 2015. $<$ http://search.ebscohost.com>. 
Sutherland, John. "Waiting for a Break That Never Came." The New York Times Book Review 3 Aug. 2003: 10. Literature Resource Center. Web. 4 May 2015. <http://go.galegroup.com>.

Waldman, Adelle. "Blaming the 'Burbs" New Republic. 22 December 2008.Web.4May2015.<https://newrepublic.com/article/64463/blamingthe-burbs>.

Woods, Sister Frances Jerome. The American Family System. New York: Harper, 1959.

Yates, Richard . Revolutionary Road. 1961. New York: Vintage-Random, 2009.

Zaretsky, Natasha. No Direction Home: The American Family and the Fear of National Decline, 1968-1980. Chapel Hill, US: North Carolina UP, 2007.

Zimmerman, Carle C. "The Family." Contemporary Sociology. Ed. Joseph S. Roucek. New York: Philosophical Library, 1985. 87-109. 